\title{
Implementasi Sensor Fusion untuk Peningkatan Akurasi Sensor GPS
}

\author{
T. A. Nugroho, M. Hutagalung, M.A. Susantio, V. Jeremias, Y. Yonata \\ Institut Teknologi Harapan Bangsa \\ tunggul@gmail.com
}

\begin{abstract}
Pada sektor transportasi dan stasiun pemantau cuaca, GPS (Global Positioning System) memegang peranan penting dalam perkembangannya. GPS seringkali mengalami kendala hilangnya sinyal atau gangguan luar lainnya, seperti cuaca buruk atau sinyal GPS yang tertahan pada lapisan atmosfer. Oleh karena itu, diperlukan suatu perangkat lain atau sensor untuk mendukung kinerja GPS. Dengan adanya sensor gyroscope dan accelerometer diharapkan dapat memperbaiki kinerja GPS dan dapat menggantikan GPS sementara apabila GPS mengalami gangguan. Pemodelan dan perancangan sebuah sensor fusion diperlukan untuk membantu kinerja dan meningkatkan akurasi GPS dalam membaca suatu posisi dan kecepatan. Implementasi sensor fusion tersebut akan memudahkan para pengguna GPS, terutama untuk navigasi agar lokasi dan kecepatan yang didapatkan lebih akurat
\end{abstract}

Kata Kunci: GPS, sensor fusion, sensor gyroscope, sensor accelerometer, stasiun pemantau cuaca

\section{Pendahuluan}

Sejak pemanfaatan GPS untuk kepentingan sipil diperbolehkan, penggunaan GPS semakin lama semakin luas, hampir seluruh lapisan masyarakat fasih menggunakan teknologi GPS. Namun adakalanya GPS receiver mengalami ketidakakuratan yang disebabkan oleh berbagai hal seperti sinyal sulit menembus lapisan Ionisfer dan Troposfer, posisi satelit, dan interferensi sinyal radio (Haryanti \& Kusumaningrum, 2010)(Ekawati, 2010).

Beberapa percobaan terkait dengan akurasi GPS sudah banyak dilakukan, salah satunya yang dilakukan oleh Mayhew yang menggunakan multi-rate sensor fusion untuk meningkatkan akurasi GPS (Mayhew, 1999). Mahasiswa dari Riau juga sudah mencoba untuk meningkatkan akurasi GPS dengan menggunakan algoritma neural network backpropagation pada sistem WPS (Susantok, Kurniawan, \& Azwar, 2013).

Sensor fusion merupakan cara yang paling banyak digunakan untuk mendapatkan akurasi yang presisi terutama untuk keakuratan GPS. Selain digunakan untuk GPS, sensor fusion juga sudah banyak diterapkan pada aplikasi lain seperti sensor fusion menggunakan accelerometer rate gyro (ARG) untuk estimasi sudut Euler pada wahana terbang (Ariyanto, 2015), implementasi sensor accelerometer, gyroscope dan magnetometer berbasis 
mikrokontroler untuk menampilkan posisi benda menggunakan Inertial Navigation System (INS) (Pramana, 2013) dan implementasi sensor fusion untuk mengukur ketinggian berdasarkan pengukuran barometer dan inersia (Sabatini \& Genovese, 2014).

Oleh karena itu, dalam penelitian ini akan dirancang sebuah sistem dari sensor fusion dengan menggabungkan GPS dengan sensor accelerometer dan gyroscope. Hasil penggabungan data dari sensor akan dimodelkan menggunakan filter Kalman dan akan disusun algoritma untuk menyelesaikan permasalahan keakuratan GPS.

Filter Kalman sudah banyak digunakan untuk berbagai aplikasi. Perhitungan dapat dibuktikan untuk menghasilkan nilai yang mendekati aslinya, bahkan sama persis. Filter Kalman dapat diaplikasikan untuk mencari multirate multisensor fusion data untuk sistem linear (Safari, Shabani, \& Simon, 2014) dan pada pesawat tanpa awak (Ardiantara, Sumiharto, \& Wibowo, 2014).

Sensor fusion yang dirancang dan diimplementasikan dalam penelitian ini akan diuji dengan cara membandingkan dengan GPS tracker smartphone dan GPS tracker device. Hasil pengujian tersebut diharapkan, nilai yang dihasilkan oleh GPS akan semakin akurat dan presisi, serta mengurangi persentase kesalahan.

Hasil akhir dari penelitian ini adalah model sensor fusion berupa perangkat keras dan perangkat lunak.

\section{Formulasi Masalah}

GPS merupakan inti dari sistem sensor fusion. Sensor GPS yang digunakan dapat dilihat pada Gambar 1. GPS menggunakan format NMEA dan mengambil nilai \$GPRMC. Format data \$GPRMC memiliki bentuk seperti dibawah ini :

\$GPRMC,030426.200,A,0653.3442,S,10736.9711,E,0.08,87.76,020317,„,A*4F.

Cara pembacaan format NMEA \$GPRMC :

1. $030426=$ Waktu Fix 03:04:26

2. A = Peringatan GPS receiver

3. (A:Baik, V:Error)

4. 0653.3442, $\mathrm{S}=$ Latitude $^{\circ}, 53.3442$ min Selatan

5. $10736.9711, \mathrm{E}=$ Longitude $107^{\circ}, 36.9711$ min Timur

6. $0.08=$ Kecepatan dalam knot

7. $020317=$ Date Fix 2 Maret 2017

Data yang akan digunakan dalam pemodelan sensor fusion adalah data latitude, longitude dan kecepatan secara real-time. Selanjutnya data tersebut akan diolah, lalu dikonversi ke format Google Maps untuk latitude dan longitude serta dikonversi menjadi $\mathrm{km} / \mathrm{jam}$ untuk kecepatan. Data tersebut akan digabungkan dengan data dari 2 sensor lain yaitu sensor gyroscope dan sensor accelerometer yang ditunjukan pada Gambar 2. Gabungan ketiga sensor tersebut akan membentuk suatu sistem sensor fusion.

Sensor gyroscope akan menghasilkan nilai kecepatan dan sudut, dimana kedua komponen ini akan menentukan posisi arah dan jarak yang akan dikonversi ke nilai posisi. Sedangkan sensor accelerometer digunakan untuk mendapatkan nilai percepatan. 


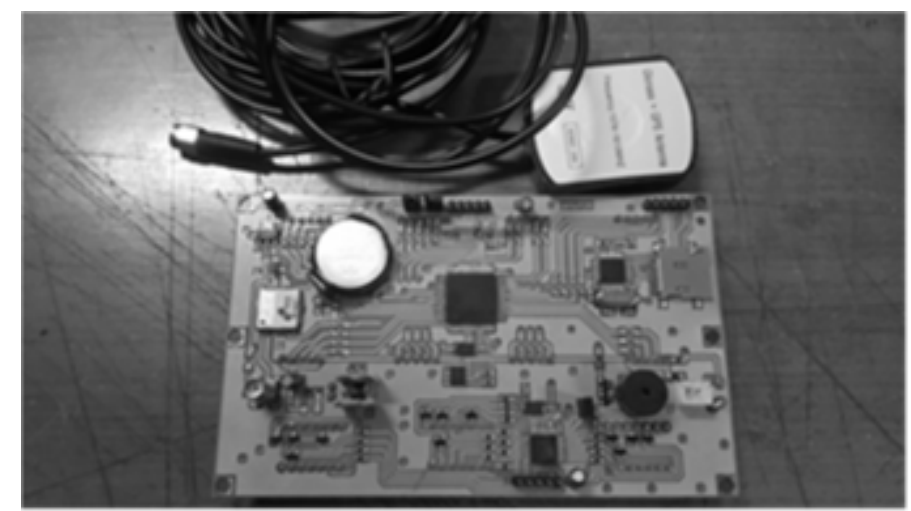

Gambar 1. Sensor GPS + Antenna
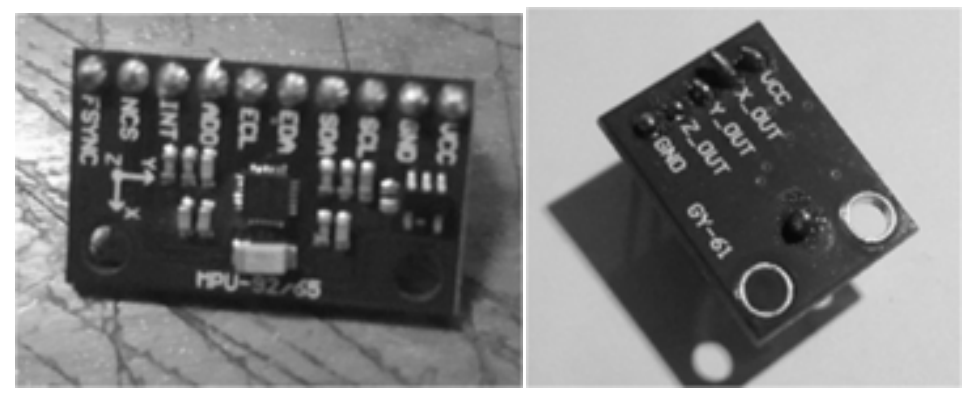

Gambar 2. Sensor gyroscope dan accelerometer

Semua komponen akan dihitung atau dimodelkan dengan model matematika filter Kalman. Filter Kalman atau yang biasa dikenal dengan Linear Quadratic Estimation (LQE) merupakan estimator yang handal. Filter Kalman dapat melakukan estimasi dengan meminimalkan noise atau konvariance.

Dalam pemodelan filter Kalman, terdapat tahapan yang harus diikuti untuk mendapatkan hasil yang terbaik. Tahapan perhitungan filter Kalman dapat dibagi menjadi 2 yaitu proses filtering dan proses fusion. Proses pertama dapat digambarkan dengan rumus berikut:

$$
x(k)=\left[\begin{array}{c}
x+\Delta t * x+\Delta t^{2} * \ddot{x}+a * \frac{1}{2} \Delta t^{2} \\
\dot{x}+\Delta t * \ddot{x}+a * \Delta t \\
\ddot{x}+a
\end{array}\right]
$$

Rumus di atas akan menunjukan posisi, kecepatan dan percepatan yang dialami masingmasing sensor. Setelah melakukan filtering pada sensor, langkah selanjutnya adalah dengan melakukan fusion pada sensor-sensor dengan perumusan sebagai berikut: 


$$
\begin{aligned}
& W=\frac{e_{e s t}}{e_{e s t}+e_{\text {mea }}} \\
& E s t_{t}=E s t_{t-1}+W\left(\text { Mea }-E s t_{t-1}\right) \\
& e_{E s t_{t}}=[1-W]\left(e_{E s t_{t-1}}\right)
\end{aligned}
$$

Keterangan rumus adalah $\mathrm{KG}=$ kalman gain, $\mathrm{e}_{\mathrm{est}}=$ estimasi error, $\mathrm{e}_{\mathrm{mea}}=$ error saat pengukuran, Est $_{\mathrm{t}}=$ estimasi saat ini, Est $\mathrm{t}_{\mathrm{t}-1}=$ estimasi sebelumnya, Mea $=$ hasil pengukuran, $e_{E s t_{t}}=$ estimasi error saat ini, $e_{E s t_{t-1}}=$ estimasi error sebelumnya. Dengan menggunakan persamaan tersebut, akan didapatkan nilai estimasi dari posisi dan kecepatan beserta estimasi errornya sehingga nilai dari proses sensor fusion ini akan mendekati nilai dari pembandingnya (true value).

\section{Algoritma dan Pemodelan Sensor fusion}

Algoritma dari sensor fusion ini disusun secara sistematis dan mudah untuk dipahami. Algoritma ini akan memiliki 2 kondisi yaitu pada saat GPS dalam keadaan aktif (A) dan GPS dalam keadaan mengalami gangguan (V) seperti pada Gambar 3.

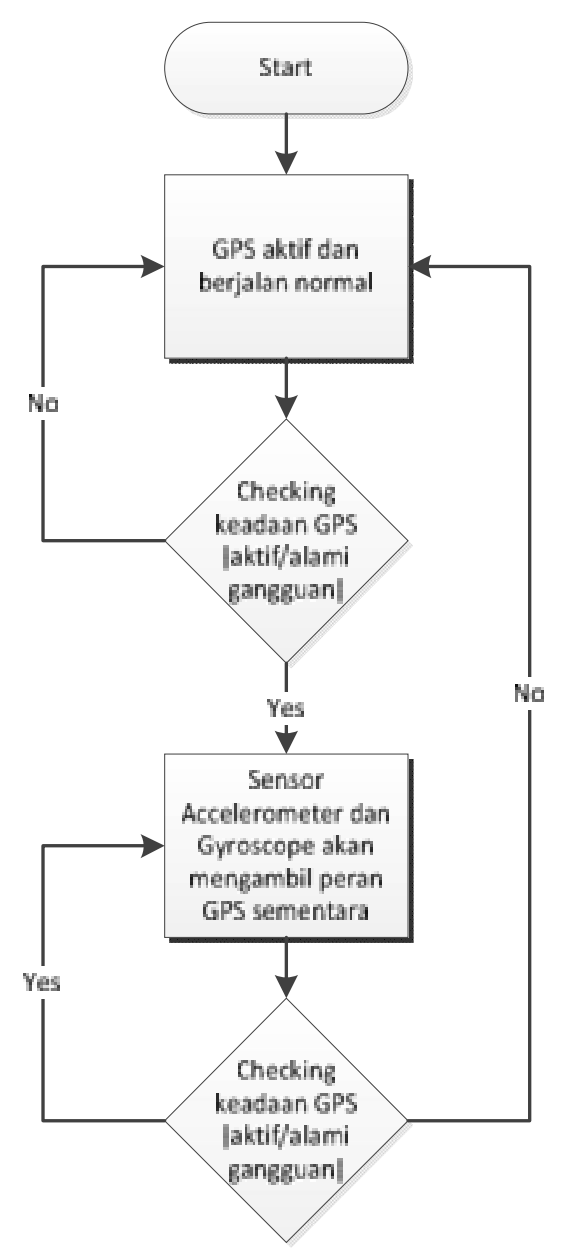

Gambar 3. Algoritma sensor fusion 
Dengan menggunakan algoritma sensor fusion dapat diketahui bahwa kondisi dari GPS akan menentukan bagaimana cara kerja dari sensor gyroscope dan sensor accelerometer sehingga kedua sensor tersebut dapat terus membantu kinerja GPS baik dalam kondisi baik maupun menjadi pengganti GPS apabila GPS sedang mengalami gangguan.

Pemodelan sensor fusion akan dilakukan dengan menggunakan model fiter Kalman dan menggunakan perangkat lunak arduino. Pemodelan akan dilakukan pada penentuan posisi dan kecepatan.

\subsection{Pemodelan Sensor Fusion untuk Posisi}

Pada pemodelan posisi akan digunakan 2 sensor yaitu sensor GPS, sensor gyroscope. Sensor GPS akan menghasilkan data posisi latitude dan longitude. Sedangkan sensor gyroscope akan menghasilkan data kemiringan sudut, jarak dan kecepatan. Pemodelan sensor fusion untuk posisi dapat dilihat pada Gambar 4.

\subsection{Pemodelan Sensor Fusion untuk Kecepatan}

Pada pemodelan posisi akan digunakan 2 sensor yaitu sensor GPS, sensor accelerometer. Sensor GPS akan menghasilkan data kecepatan. Sedangkan sensor accelerometer akan menghasilkan data percepatan. Pemodelan sensor fusion untuk posisi dapat dilihat pada Gambar 5.

\section{Pengujian Sensor fusion}

Pengujian sensor fusion secara garis besar dibagi kedalam 2 bagian, yaitu pengujian posisi dan pengujian kecepatan. Pengujian posisi longitude dan latitude dapat dikatakan akurat apabila memiliki margin error sekitar $300 \mathrm{~m}$. Pengujian posisi longitude dan latitude dapat dikatakan akurat apabila memiliki margin error sekitar $4 \mathrm{~km} / \mathrm{jam}$. Berikut beberapa skenario pengujian yang dilakukan:

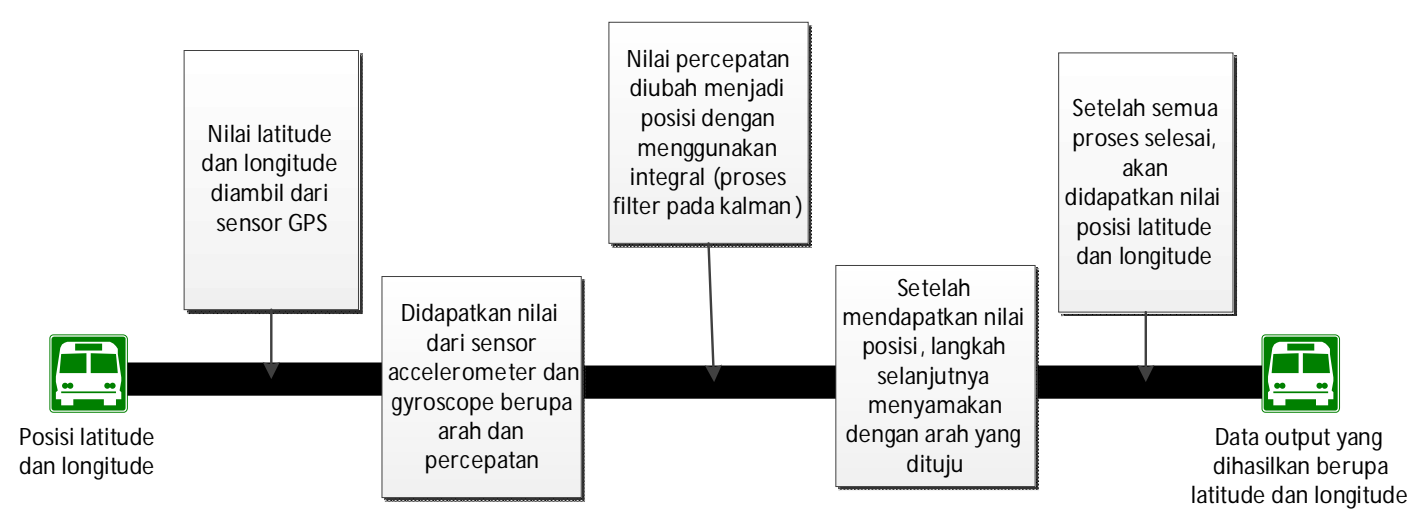

Gambar 4 Pemodelan posisi latitude dan longitude 


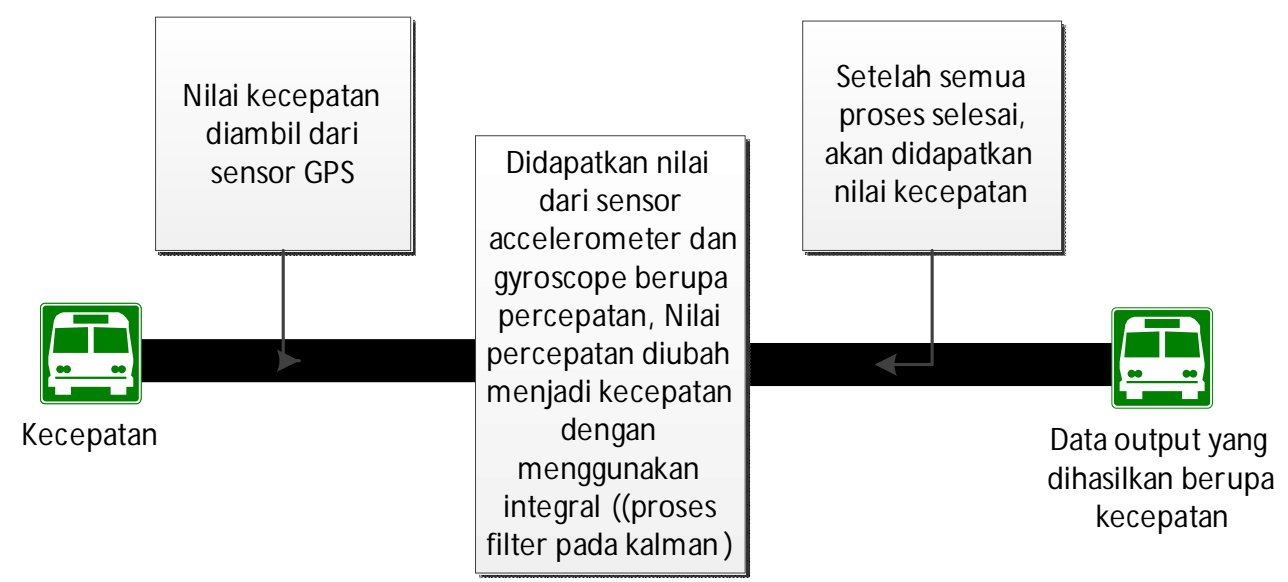

Gambar 5 Pemodelan kecepatan

\subsection{Pengujian posisi dengan sensor fusion}

Sensor fusion perlu diuji untuk mengetahui seberapa akurat posisi yang ditunjukannya. Pengujian ini dilakukan dengan membandingkan nilai yang dihasilkan oleh sensor fusion, GPS tracker smartphone dan GPS tracker device. Langkah pertama, ketiga perangkat tersebut dibawa ke sebuah lokasi lalu berhenti di situ. Pada saat itu, sensor fusion dan GPS tracker akan menghasilkan data pembacaan posisi, kemudian data tersebut direkam oleh masingmasing perangkat. Hasil rekaman ini akan disimpan dalam file Excel. Contoh hasil data yang disimpan tersebut dapat dilihat pada Gambar 6.

Format GPS yang digunakan dalam pengujian ini adalah format dari Google Maps. Gambar 7 menunjukan grafik perbandingan latitude dan longitude antara sensor fusion, GPS tracker smartphone dan GPS tracker device. Antara sensor fusion dengan GPS tracker smartphone margin error latitude sekitar $0.47 \mathrm{~km}$ dan margin error longitude sekitar $0.22 \mathrm{~km}$, sedangkan antara sensor fusion dengan GPS tracker device margin error latitude sekitar 0.8 $\mathrm{km}$ dan margin error longitude sekitar $0.25 \mathrm{~km}$.

Kesimpulan yang dapat diambil dari pengujian posisi ini adalah nilai sensor fusion terhadap GPS smartphone kurang akurat, hal ini dapat terjadi karena kondisi GPS smartphone yang kurang stabil. Sedangkan nilai sensor fusion dengan GPS device dapat dikatakan akurat karena masih dalam batas margin error. Margin error dari pengujian sensor fusion terhadap GPS tracker device dapat dilihat pada gambar 8.

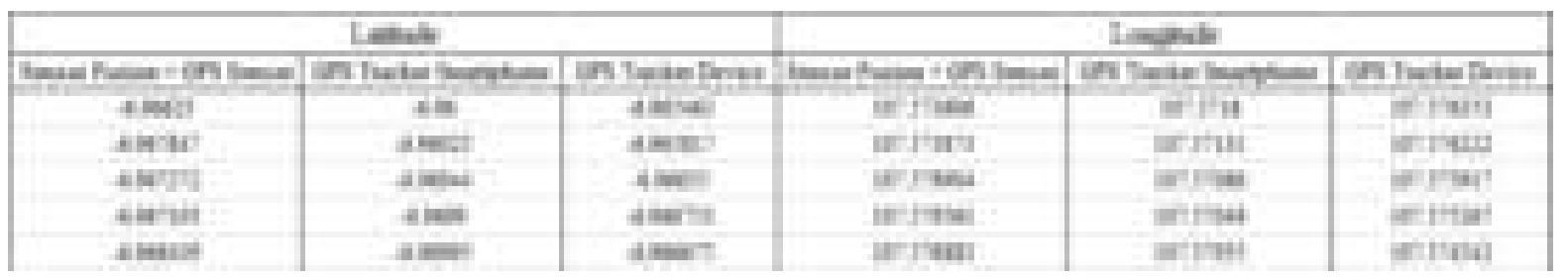

Gambar 6 Hasil data yang disimpan 


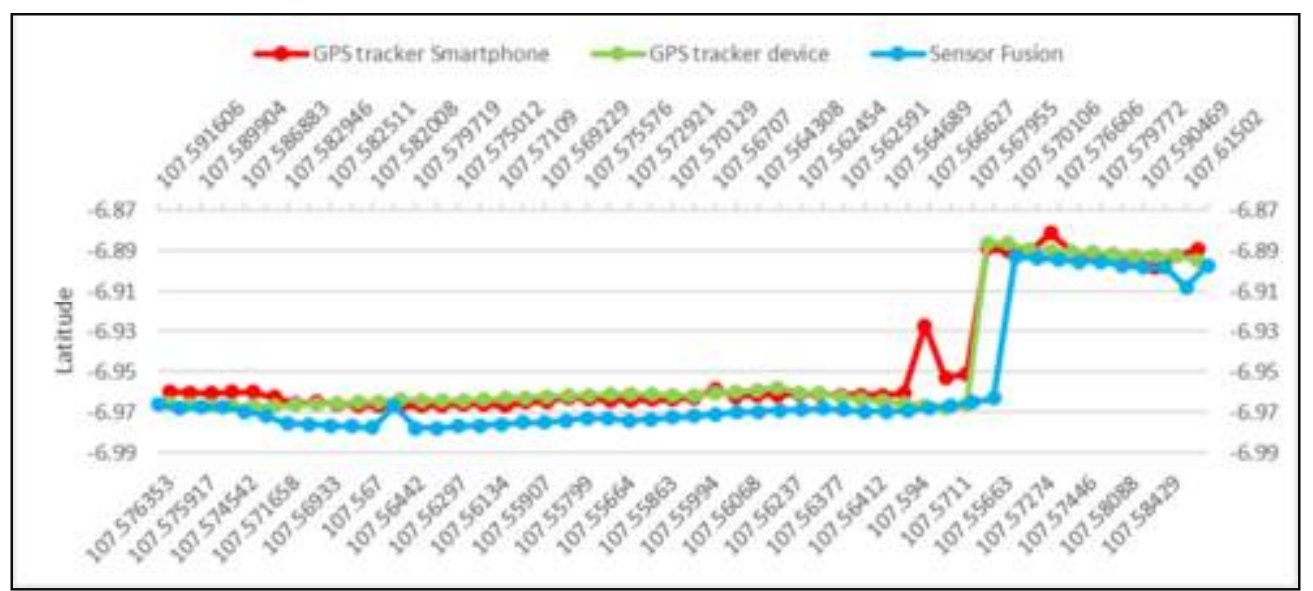

Gambar 7 Hasil perbandingan latitude antara sensor fusion, GPS tracker device, dan GPS tracker smartphone

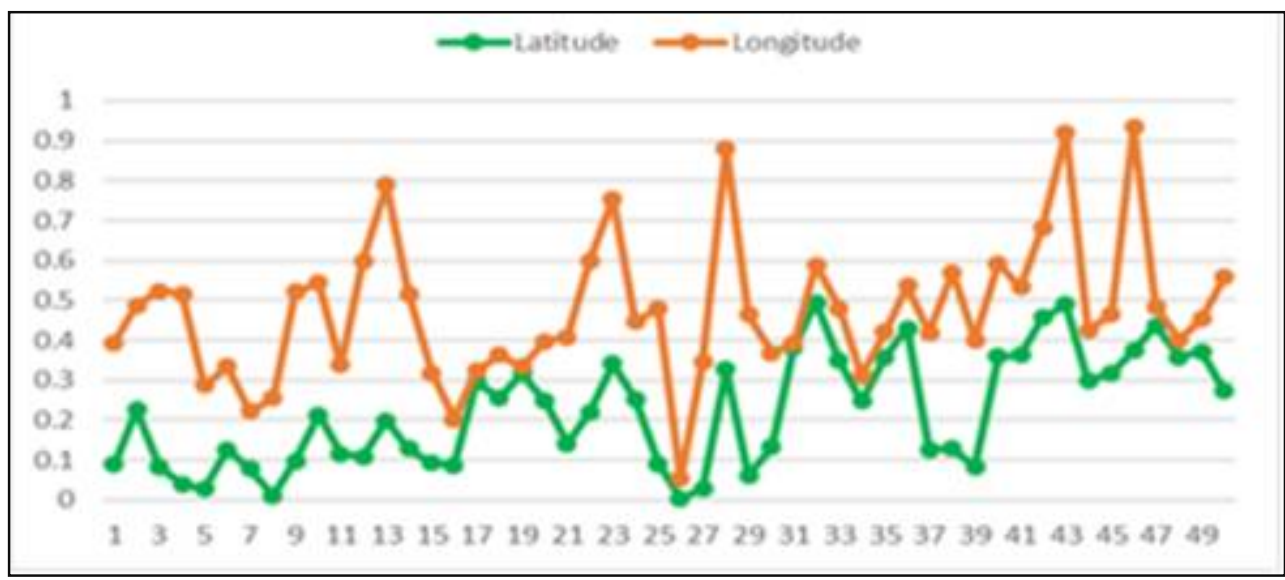

Gambar 8 Hasil perbandingan latitude antara sensor fusion, GPS tracker device, dan GPS tracker smartphone.

\subsection{Pengujian kecepatan dengan sensor fusion saat kecepatan konstan dan tidak konstan}

Sensor fusion perlu diuji untuk mengetahui seberapa akurat kecepatan baik saat konstan maupun saat tidak konstan. ini dilakukan dengan membandingkan nilai yang dihasilkan oleh sensor GPS, sensor fusion dan true value. True value yang digunakan pada pengujian ini adalah speedometer dengan asumsi nilai yang dihasilkan akurat atau ideal. Langkah pertama, ketiga perangkat dibawa dengan menggunakan mobil. Mobil tersebut akan terus bergerak dan sensor fusion, sensor GPS serta speedometer akan menghasilkan data pembacaan kecepatan, kemudian data tersebut direkam oleh masing-masing perangkat. Pengujian akan dilakukan sebanyak 2x, pengujian 1 pada sensor fusion dalam kondisi kecepatan konstan dan pengujian 2 sensor fusion dalam kondisi kecepatan tidak konstan. Hasil perbandingan kecepatan konstan dapat dilihat pada gambar 9.

Pada gambar 9 kecepatan dari sensor fusion dibandingkan dengan Speedometer memiliki margin error sekitar $1.57 \mathrm{~km} / \mathrm{jam}$. Kesimpulan yang dapat diambil dari pengujian kecepatan konstan ini adalah nilai sensor fusion dengan Spedometer memiliki nilai yang 
akurat karena masih dalam batas margin error. Gambar 10 menunjukan grafik dari error yang di alami oleh sensor fusion dalam persentase.

Hasil analisa pada grafik margin error pada sensor fusion kecepatan konstan dengan spedometer mengalami penurunan sehingga dapat dikatakan nilai kecepatan akan menjadi semakin akurat. Hasil perbandingan kecepatan tidak konstan dapat dilihat pada gambar 11.

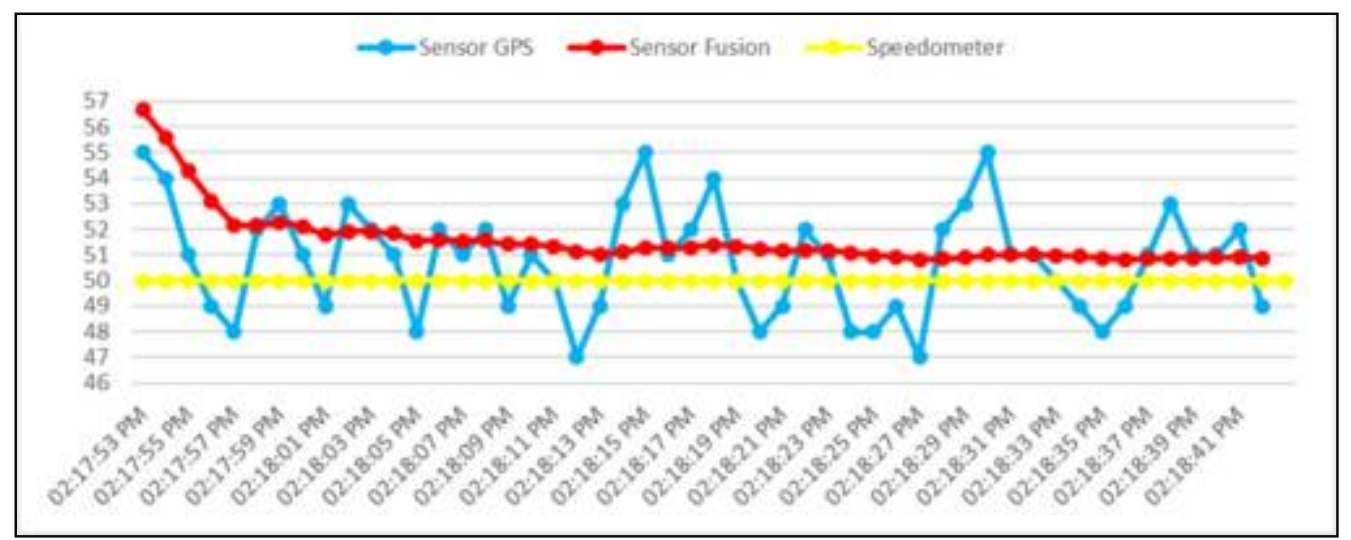

Gambar 9 Hasil perbandingan antara measurement saat ini (sensor GPS), estimasi saat ini (sensor fusion) dan true value (spedometer).

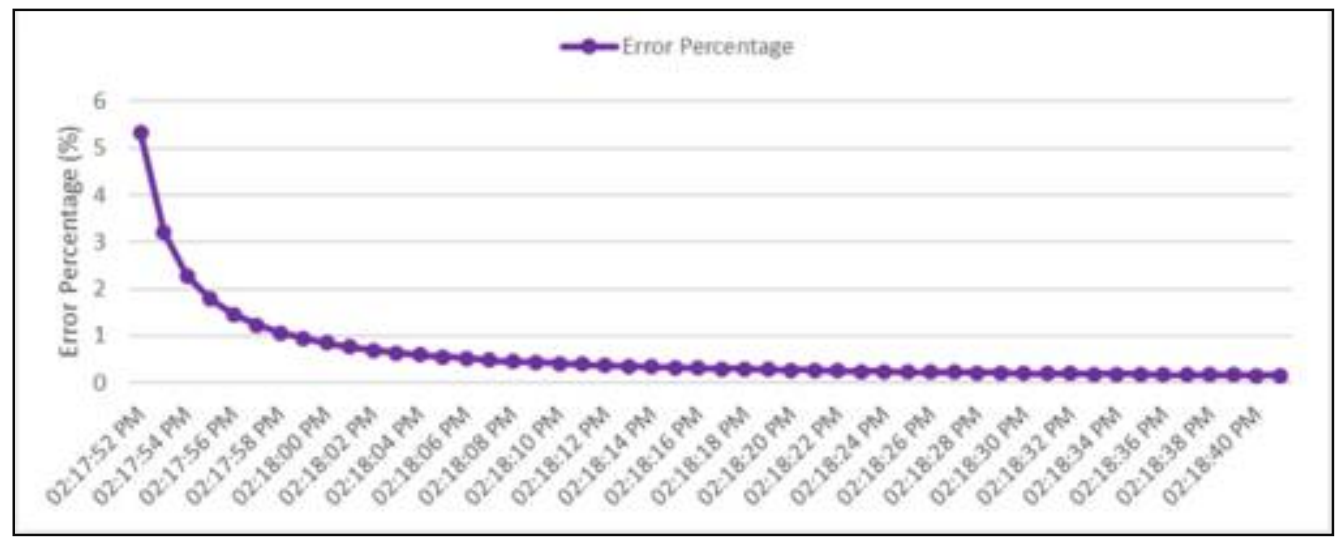

Gambar 10. Hasil persentase error yang dialami oleh sensor fusion pada kecepatan konstan

Pada gambar 11 kecepatan dari sensor fusion dibandingkan dengan Speedometer memiliki margin eror sekitar $5.86 \mathrm{~km} / \mathrm{jam}$. Kesimpulan yang dapat diambil dari pengujian kecepatan tidak konstan ini adalah nilai sensor fusion dengan Spedometer memiliki nilai yang tidak akurat. Hal ini disebabkan karena filter Kalman melakukan perbaikan pada sensor GPS dengan cara bertahap dan perlahan sehingga apabila kecepatan tidak konstan maka nilai dari sensor fusion akan mengalami eror yang cukup besar namun perlahan mampu mendekati true value. Gambar 12 menunjukan grafik dari eror yang di alami oleh sensor fusion dalam persentase.

Hasil analisa pada grafik margin error pada sensor fusion kecepatan tidak konstan dengan spedometer mengalami penurunan meskipun tidak selalu turun karena disebabkan 
error pada sensor saat pengukuran sehingga dapat dikatakan nilai kecepatan akan menjadi semakin akurat.

\subsection{Pengujian kecepatan dengan sensor fusion saat kecepatan naik dan turun secara konstan}

Sensor fusion perlu diuji untuk mengetahui seberapa akurat kecepatan baik saat kecepatan naik maupun turun. ini dilakukan dengan membandingkan nilai yang dihasilkan oleh sensor GPS, sensor fusion dan true value. True value yang digunakan pada pengujian ini adalah speedometer dengan asumsi nilai yang dihasilkan akurat atau ideal. Langkah pertama, ketiga perangkat dibawa dengan menggunakan mobil. Mobil tersebut akan terus bergerak dan sensor fusion, sensor GPS serta speedometer akan menghasilkan data pembacaan kecepatan, kemudian data tersebut direkam oleh masing-masing perangkat. Hasil perbandingan dapat dilihat pada gambar 13 .

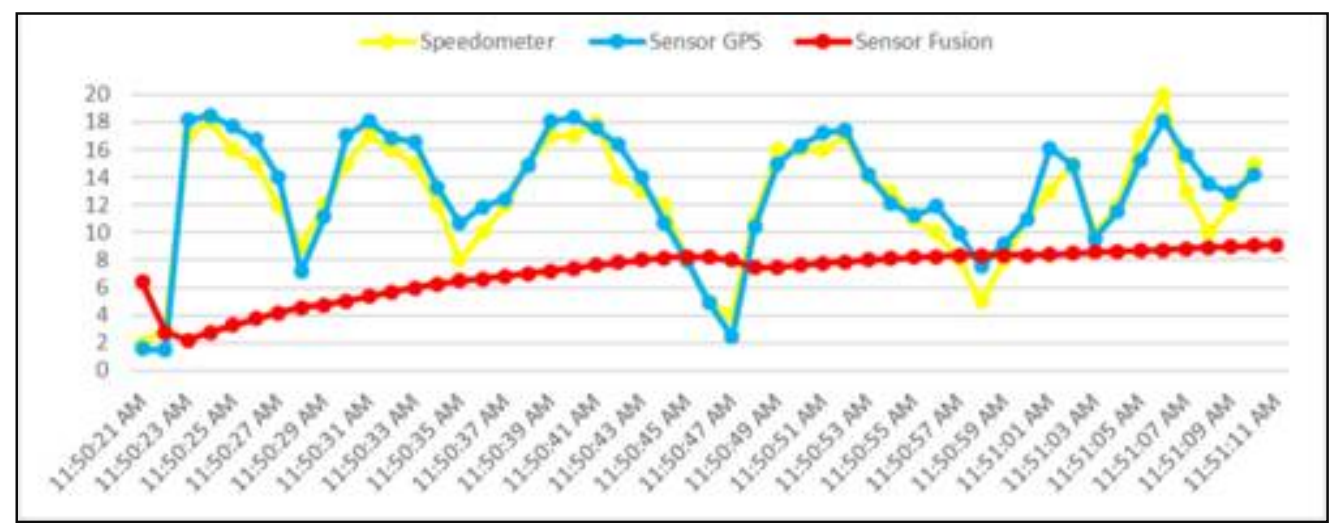

Gambar 11 Hasil perbandingan antara measurement saat ini (sensor GPS), estimasi saat ini (sensor fusion) dan true value (spedometer).

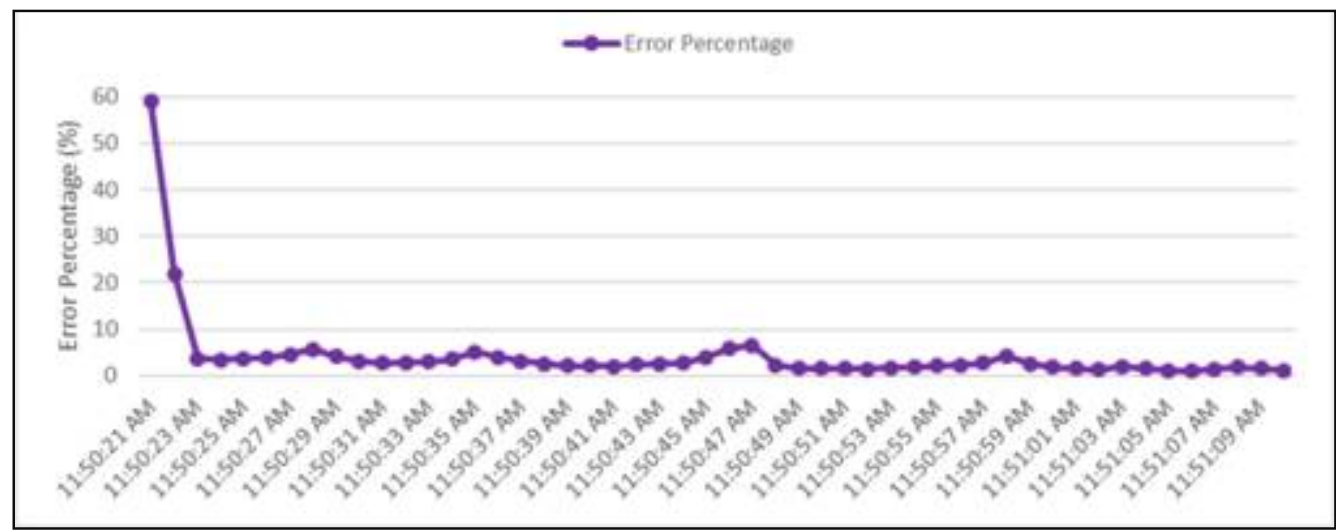

Gambar 12 Hasil persentase yang dialami oleh sensor fusion pada kecepatan tidak konstan

Pada Gambar 13 kecepatan dari sensor fusion dibandingkan dengan Speedometer memiliki margin error sekitar $14.33 \mathrm{~km} / \mathrm{jam}$. Kesimpulan yang dapat diambil dari pengujian kecepatan ini adalah nilai sensor fusion dengan Spedometer memiliki nilai yang tidak akurat. Hal ini disebabkan karena filter Kalman melakukan perbaikan pada sensor GPS dengan cara 
bertahap dan perlahan sehingga apabila kecepatan naik dan turun secara konstan maka nilai dari sensor fusion akan mengalami error yang cukup besar, kemungkinan besar hal ini disebabkan oleh kesalahan pada perhitungan. Gambar 14 menunjukan grafik dari error yang di alami oleh sensor fusion dalam persentase.

Hasil analisa pada grafik margin error pada kecepatan sensor fusion kecepatan tidak terlalu terlihat karena pada awal pengujian error yang dialami cukup besar dan error yang dialami oleh sensor cukup bervariasi dan tidak stabil.

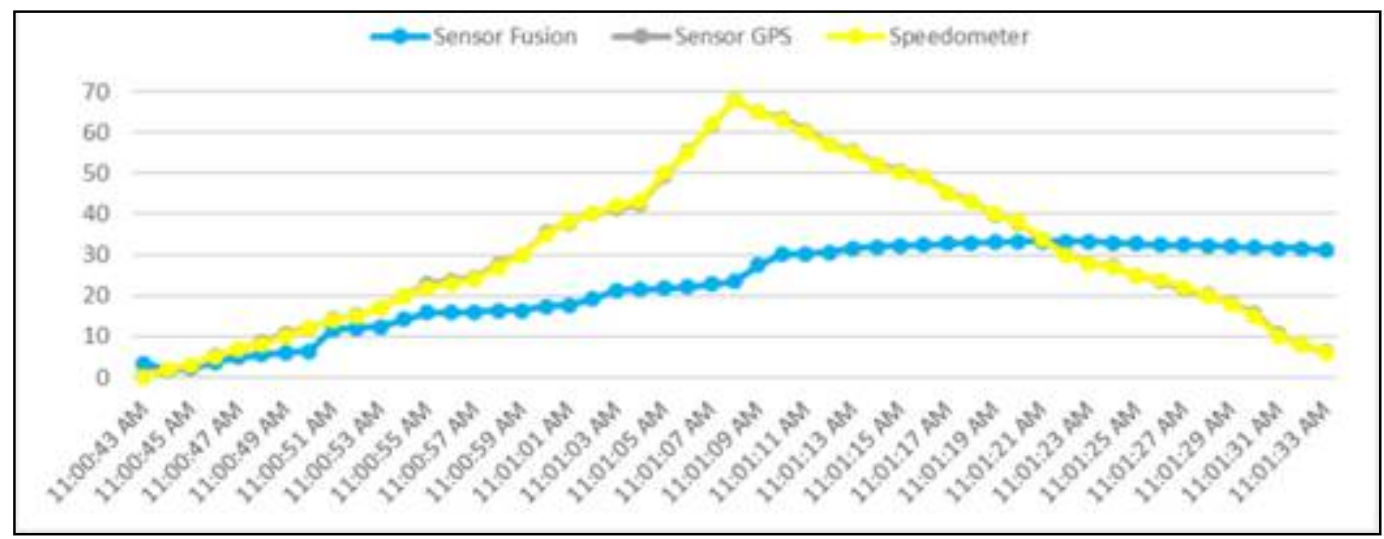

Gambar 13 Hasil perbandingan antara measurement saat ini (sensor GPS), estimasi saat ini (sensor fusion) dan true value (spedometer).

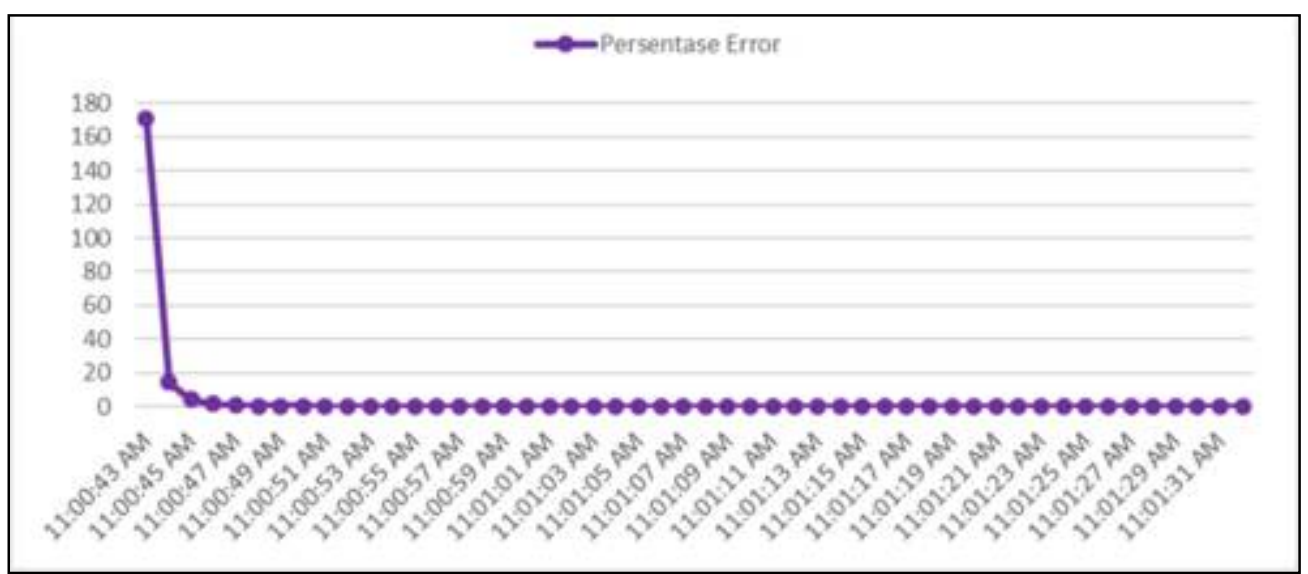

Gambar 14 Hasil persentase yang dialami oleh sensor fusion pada kecepatan naik dan turun secara konstan

\section{Kesimpulan}

Berdasarkan hasil analisis, perancangan, pemodelan, implementasi dan pengujian maka dapat diambil kesimpulan sebagai berikut:

1. Dalam pengujian posisi latitude dan longitude sensor fusion dapat bekerja dengan baik dan akurat dengan margin masih dibawah 300m. Sedangkan dalam kondisi tanpa GPS error dari sensor fusion cukup besar semakin lama sehingga dapat dikategorikan tidak akurat.

2. Dalam pengujian kecepatan sensor fusion dapat bekerja dengan baik dan akurat pada saat kecepatan konstan, sedangkan pada saat kecepatan tidak konstan, error yang terjadi cukup 
besar. Pada saat sensor fusion berdiri sendiri tanpa sensor GPS nilai error yang terjadi cukup besar dan rata-rata berada diatas margin error sehingga dapat dikategorikan tidak akurat.

Sensor fusion yang dirancang dan dimodelkan masih kurang sempurna. Oleh sebab itu perkembangan kearah yang lebih baik maka perlu dilakukan perbaikan untuk meningkatkan keakuratan. Adapun saran-saran terhadap pengembangan sistem sensor fusion pada GPS ini sebagai berikut:

1. Menggunakan algoritma selain kalman filter untuk mencari algoritma yang paling baik untuk diterapkan pada sistem sensor fusion pada GPS ini.

2. Mencari penyebab error yang terjadi pada saat pengujian sensor fusion kecepatan tidak konstan.

\section{Ucapan Terima Kasih}

Penelitian ini didanai dalam program hibah Penelitian Produk Terapan Tahun Anggaran 2017 untuk bidang riset Teknologi Informasi oleh Kementrian Riset, Teknologi dan Pendidikan Tinggi melalui Koordinator Perguruan Tinggi Swasta Wilayah IV Jawa Barat-Banten.

\section{Daftar Referensi}

Ardiantara, P. S., Sumiharto R., \& Wibowo, S. B. (2014). Purwarupa Kontrol Kestabilan Posisi dan Sikap pada Pesawat Tanpa Awak Menggunakan IMU dan Algoritma Fusion Sensor Kalman Filter. IJEIS (Indonesian Journal of Electronics and Instrumentation Systems), 4(1), 25-34. http://doi.org/10.22146/ijeis.4219.

Ariyanto, M. (2015). Sensor Fusion Menggunakan Accelerometer Rate Gyro (ARG) untuk Estimasi Sudut Euler pada Wahana Terbang. ROTASI, 17(2), 84-92.

Ekawati, S. (2010). Pengaruh Geometri Satelit dan Ionosfer dalam Kesalahan Penentuan Posisi GPS. Berita Dirgantara, 11(Juni), 59-65.

Haryanti, M., \& Kusumaningrum, N. (2010). Aplikasi Accelerometer 3 Axis Untuk Mengukur Sudut Kemiringan (Tilt) Engineering Model Satelit di Atas Air Bearing. TESLA Jurnal Teknik Elektro UNTAR, 10(2), 55.

Mayhew, D. M. (1999). Multi-rate sensor fusion for GPS navigation using Kalman filtering. Virginia Polytechnic Institute and State University.

Pramana, Y. A. (2013). Implementasi Sensor Accelerometer, Gyroscope Dan Magnetometer Berbasis Mikrokontroler Untuk Menampilkan Posisi Benda Menggunakan Inertial Navigation System (Ins). Indonesia Computer University.

Sabatini, A. M., \& Genovese, V. (2014). A sensor fusion method for tracking vertical velocity and height based on inertial and barometric altimeter measurements. Sensors (Switzerland), 14(8), 13324-13347. http://doi.org/10.3390/s140813324.

Safari, S., Shabani, F., \& Simon, D. (2014). Multirate multisensor data fusion for linear systems using Kalman filters and a neural network. Aerospace Science and Technology, 39, 465-471. http://doi.org/DOI 10.1016/j.ast.2014.06.005.

Susantok, M., Kurniawan, A., \& Azwar, H. (2013). Wifi Positioning System (WPS) Menggunakan Algoritma Neural Network Backpropagation di Area Kampus Politeknik Caltex Riau. Jurnal Teknik Elektro Dan Komputer, 1(2), 130-141. 